\title{
Pioneering in Women's Medical Education in the Swiss Universities 1864-1914
}

\author{
By Thomas N. Bonner
}

In the years before 1914 no country made so decisive a contribution to the medical education of women as Switzerland. For fifty years, from the admission of the first Russian woman to medical lectures at Zürich in 1864 to the outbreak of the First World War, thousands of women-Russian, Polish, East European, German, Austrian, English, American - made their way to the young universities in Zürich, Bern, Geneva, and Lausanne. They came at first in small groups of two or three, then in dozens, then in hundreds, until by 1906 a total of 1150 foreign women were enrolled in medicine alone, while another 750 were studying other professions. A century later it is hard to visualize the teeming colonies of foreign women, mostly Russian but sprinkled with numbers of West Europeans and Americans, who poured into the comfortable old Wohnhäuser on the Oberstrasse in Zürich and later into the crowded student quarters of Bern and Geneva. It was a migration of professional women across national boundaries without parallel in history. Why did they come? Where did they come from? Why did the universities of tiny Switzerland accept them? How did the Swiss experience affect their later lives and careers?

They came chiefly because in the entire world before 1867 no reputable medical school consistently allowed women to enter. The first modern woman doctor, Elizabeth Blackwell, had graduated from the small, rural medical school in Geneva, New York, in 1849 after two brief terms of study but even that school had subsequently closed its doors to women. In America, a number of sectarian medical schools had begun to admit women and in Boston and Philadelphia special schools for the medical training of women had been started. But Harvard, Pennsylvania, and other leading schools remained firmly closed to them and Europeans had little regard for the products of the irregular and women's schools. "Most of these women doctors in America," said Professor Wilhelm von Zehender of Rostock in a widely disseminated article in 1875 , "do not stand in very high regard" (46, p. 19). Even the best American schools, as William Henry Welch discovered in the 1870 's, provided a meager medical education that was hopelessly behind the German universities. In the medical centers of Great Britain, 
France, Germany, and other European countries, on the other hand, no modern woman had been allowed to enroll in medicine anywhere, though several had tried to gain admission. Nowhere in Europe were women admitted to the strenuous secondary schools that alone qualified a student for admission to the university (38).

Yet across the western world in the 1860 's a social revolution was transforming the traditional relationships of women to the family and the world of work. The economic changes of the previous century, together with the liberating ideas unloosed by the French Revolution, had made the "woman question" a subject of political and social interest in nearly every country. Particularly in the ascendant middle classes was the new diminished role of women within the family a source of anxious concern. To many men in the rising merchant and professional class, it became a matter of pride that wives and daughters had no need to work. But to a growing number of women and their liberal supporters education was increasingly seen as the first step to economic opportunity and independence outside the diminished family.

The quest for higher education met special obstacles in the case of medicine. Did women possess the high intellectual capacity necessary to master a learned profession? Were pregnancy and menstruation not insuperable barriers to a profession where constant attention to duty was an indispensable requirement? Did women have the physical strength to practice medicine and surgery? Would anatomical study and dissection not destroy the special sensibilities of women? Would the presence of women in mixed classes inhibit the medical professors and their fellow students? These questions were earnestly debated among medical men in the closing decades of the nineteenth century. The renowned Munich anatomist Theodor von Bischoff argued to his death that woman's smaller brain, her physical weakness, and her gentle nature unfitted her for medical science (3). His reputation and wide influence affected several generations of medical practitioners. Likewise, other leading figures in the medical profession - the surgeon Albert in Vienna, the gynecologist Runge in Göttingen, the anatomist Waldeyer in Berlin, the neurologist Möbius in Leipzig, and others-took up their pens to argue vehemently against the movement to admit women to the profession (see $1,21,28,43$ ).

The movement to admit women had its focus in the 1860's in Switzerland in the medical school at Zürich. For the next half-century the authorities at Zürich, followed by Bern, Geneva, and then Lausanne consistently opened 
their doors to women medical students. Some women stayed only a semester or two; others stayed three or four years; still others completed the entire medical course of five to six years and wrote a doctoral thesis for the medical degree. A number of the foreign women had already had some medical training at home or were able to complete their degrees in special women's colleges in Russia and England. If even an average stay of four semesters is estimated, then more than seven thousand women from foreign countries pursued a medical course in Switzerland between 1864 and 1914. The medical enrollment of women in the universities of tiny Switzerland in the early twentieth century was greater than that of the rest of Europe combined and also exceeded the female enrollment of the 150 medical schools of all kinds in the United States.

How did it happen? Why did Switzerland lead the world for half a century in the medical education of women? As a small neutral country in central Europe, Switzerland had long stood at the vortex of European politics. Its borders were open to political dissidents and refugees from the great powers that surrounded it. Its political and intellectual life were subject to the swirling tides of reform emanating from France and the revolutions of 1830 and 1848. Its economy benefitted from the gigantic expansion of trade and industry in nineteenth-century Europe. Its cities were in the process of becoming centers of international commerce and services. And its universities had been newly created and were being fashioned along the lines of the dominant democratic liberalism of mid-century Switzerland. Only the University of Basel, founded in 1460 and steeped in long-established custom, failed to follow the examples of Zürich (founded in 1833) and Bern (1834), and later Geneva and Lausanne in opening wide its doors to women.

The young university in Zürich benefitted both from the liberal government of the canton and the stream of German refugees escaping the repressions that followed the uprisings of 1830 and 1848. Of Jakob Henle, who came to Zürich in 1840 , it was said that he, like others, felt a kind of political banishment from Germany in being forced to win his academic spurs in Switzerland (37, P. 10). Politics played a role, too, in the decision of Johannes Schönlein to come to Zürich after his suspension at Würzburg (37, p. 10). And Karl Ewald Hasse, who was in Zürich until 1852, called the city "a peaceful island in a stormy ocean" (37, p. 47). A large number of German academics came in the wake of the failed uprisings of 1848. Some gave public lectures in Zürich, after the German fashion, and often they were attended by as many women as men so that the sight of women in the university was no 
longer unfamiliar (45, pp.75-6). Several women auditors attended the regular university lectures in the 1840 's and 1850 's. The reputation of the university grew as it attracted a number of promising young professors, who saw Zürich as an excellent stepping-stone to a major chair in Germany. The rising young surgeon, Theodor Billroth, who was in Zürich form 1860 to 1867 , called it an "academic waiting station first class" (13, p. 552). By the 1860 's, Zürich, like Bern and Basel, was an important part of the German university world.

When the first Russian woman, Maria Kniaschnina, applied for permission to attend medical lectures at Zürich in late 1864 (B, letters 28 November 1864 and 15 January 1865), it occasioned little discussion. She did not matriculate and there was ample precedent for women auditors in the university. After several courses of lectures, she left the university without incident. A second Russian woman, Nadezhda Suslova, the daughter of a serf and committed to nihilism and radical feminism, arrived in 1865 and likewise followed the medical lectures. Two years later, however, the shy, diligent, and strongly disciplined Suslova asked to be admitted to the medical examinations (36, p.59). The educational officials of the canton turned to the medical faculty, who sympathetically responded that she must first be matriculated (C, 29 January 1867). The cantonal educational office promptly enrolled her retroactively, which made her eligible to take the examinations (B). In August she took the oral examination and on December 14, 1867, before a full auditorium, she was examined on her thesis on the physiology of the lymph glands and given her degree (6, p. 2). She was the first woman in the modern world to win a medical degree from a recognized university with high academic standards.

The quiet success of Suslova launched the first wave of women students to reach Zürich. Within three years, there were twelve women in the medical school, seven of them from Russia, three from Great Britain, one from the United States, and the first Swiss woman, Marie Vögtlin (15, p. 52). Many of them became prominent in their homelands-Frances Morgan, Louise Atkins, and Eliza Walker in Great Britain; Marie Vögtlin in Switzerland; Susan Dimock in the United States; and Maria Bokova, Pulcheria Jakovleva, and Anna Kleinmann in Russia. They were followed by Emilie Lehmus and Franziska Tiburtius, the pioneer women physicians in Germany, and somewhat later by Baronness Gabriele von Possaner, the first woman to practice medicine in Austria (27, pp. 21-45). Women became much more prominent in the lecture halls of Zürich, in the rooming houses, and on the 
streets around the university. When Frances Morgan, the self-possessed, confident Englishwoman faced the rector and faculty at her thesis defense in 1870, more than 400 faculty and students including fifty women, crowded into the great Aula to witness the second doctoral examination of a woman (7, pp. 1-2). As remembered by the psychiatrist August Forel, who was a fellow-student of Morgan's, the dean of the medical faculty, Anton Biermer, attacked the main conclusions of her thesis on progressive muscular atrophy unstintedly for twenty-five minutes but the redoubtable Morgan cooly took notes during the attack and then answered him at length, winning Biermer's praise (12, pp.45-6).

Nowhere in Europe or America could so liberally-minded and sympathetic a medical faculty have been assembled to hear the case for women's education as in Zürich. Biermer himself was an early convert to women's education. The surgeon Edmund Rose, suggested by Billroth as his successor, was a passionate defender of the experience with women at Zürich. The university, he said publicly in 1874, had already successfully concluded the "experimentum crucis" in women's education (13, p.640 n). Another champion was the histologist Heinrich Frey who had left Göttingen to come to the freer environment of Zürich in 1848 and in 1867 became a Swiss citizen (Neue Deutsche Biographie 5, 417-8). Hermann von Meyer, professor of anatomy and later dean and rector of the university, was highly regarded by the women students for his fairness and friendly attitude $(19$, p. $71 ; 40$, p. 133). And the physiologist Ludimar Hermann, though he was strongly skeptical of women's role in medicine, nevertheless defended the Zürich experiment in an open reply to Theodor Bischoff that received wide attention. Many women here, he wrote, "have won the high respect of teachers and fellow students by their industry and energy" (17, pp. 17-18). All of these men served in the University Senate, along with such staunch defenders of women's education as the liberal political economist Viktor Böhmert and the geologist Albert Heim (D).

The success of Suslova and the other Russian women unloosed a torrent of migration from Russia and Eastern Europe. Nearly a hundred women, many of them young and ill-prepared, took their places in the medical lectures and demonstrations at Zürich by 1873. Many were sympathetic to the radical political movements that were then sweeping Russia and found in medicine an outlet for their ideals of self-sacrifice and service to the people. Tiburtius remarked on their extraordinary altruism, their enthusiasm for their beliefs, their communal life, and the aptitude they showed for medical 
study $(40$, p. 128). But the sudden massive increase of women, their strange dress and habits, their lack of preparation brought danger to the Zürich experiment in women's education. The male students complained vehemently to the rector about their poor preparation and the crowding in the laboratories, a number of faculty members shared the concern of the students, and townspeople were openly critical of the university. But the government stood firm against the demands for sharp restrictions on the number of foreign students. The tension was broken by the Russian government itself when it published in June, 1873 a ban on further study by women in Zürich, arguing that the radical ringleaders of Russian emigration in the city-Bakunin and Lavrov were among them - were "luring learning youth into their net". The women were urged to return home where plans were being made for a four-year medical course to educate "learned midwives" (41, pp.3-6).

The Russian ukase ended the first great wave of female migration to the medical school at Zürich. The enrollment of women fell to eighteen in the fall of 1873 and remained under twenty-five for the next decade. Included in this number were a number of German, American, and Austrian women who came to Zürich during this period. In the meantime, the Russians scattered to Bern, Geneva, and Paris, as well as to the Russian homeland itself. At Bern, twenty of the Russian women from Zürich were enrolled in medicine in the fall of 1873. Unlike Zürich, the shock of change came swiftly as women suddenly occupied a sixth of the places in the school of medicine. But here again liberal voices in the university and the cantonal government defended the right of foreign women to study in Bern. The rector of the university, Professor Hans von Scheel, made a strong statement to the whole university community, arguing the need and justice of an expansion of women's professional opportunities. To those who criticized the large numbers of Russian women, he responded that a cosmopolitan university could not admit male students from abroad and then close its doors to women (31, p. 14). The Russian women were soon joined by a smaller number of women from Poland, Germany, Austria, America, and Eastern Europe. As in Zürich, a wave of xenophobia swept through the student body and the city itself but the government and the faculty, which included such renowned figures as the surgeon Theodor Kocher, the pathologist Theodor Langhans and later Hugo Kronecker in physiology, Hermann Sahli in medicine, and Josef Jadassohn in dermatology, resisted the pressure to restrict enrollment (30, pp. 85-7). 
A similar development took place in Geneva and later in Lausanne. At Geneva, which opened its medical school in 1876, the Polish-born Sigismund Laskowski in anatomy and Moritz Schiff, a veteran of the revolutions of 1848, in physiology, along with Schiff's successor, Jean-Louis Prevost, were champions of both women's education and the international character of the student body $(8$, pp. $23,37,43)$. The radical party in Geneva strongly supported the politics of university expansion and the opening of the university to women and foreigners. Without the international thrust, it was argued, a dynamic university in league with a thriving city could not be supported from local interest alone. Said councilman James Fazy, in arguing before the Grand Council for the necessity of a medical school: "Erlangen, Tübingen - cities no more important than Geneva-possess a medical school" (23, pp.515-16). Likewise in Lausanne the medical faculty, which began instruction in 1890, was drawn from men sympathetic to the great social changes in Swiss higher education. Only the faculty at Basel, which reluctantly admitted women in 1890 , consistently discouraged their enrollment by its strict requirements for admission and its reputation for antifeminism (36, p. 203).

By 1890, after a quarter-century of women's medical education in Switzerland, the number of women, now including a small number of Swiss students, had climbed to 150 . The numbers tripled again during the decade of the nineties as events in Russia and Eastern Europe began to inhibit further study by women at home. Then, in 1900, three of the four women's medical schools in Russia were closed completely, sending a flood of women westward to Switzerland and Paris. Bern and Geneva, particularly, became the favorite medical schools for the Russian women, while German women continued to prefer Zürich. The Revolution of 1905 added to the flow of those seeking asylum and opportunity in the West. The enrollment of women studying medicine in Swiss universities jumped from 554 in 1900 to 836 in 1902 and then to 1181 in 1906, remaining over a thousand to 1909, when the floodtide began to abate. By this time, the proportion of foreign students, largely women, had reached 68.7 per cent in the medical school at Bern, 70.5 per cent in Lausanne, and a staggering 77.4 per cent in Geneva, compared to 54.5 per cent in Zürich $(26$, p. 20). A new wave of xenophobia spread across the university cities of Switzerland. In Geneva, a movement was launched to levy a special tax on foreign students but was resisted by the faculty and local officials (23, pp.528-9). At Bern, the medical faculty turned down a move to restrict the foreign women to the clinical departements of the city 
hospital (A, letter from dean to Regierungsrat, 1905). Everywhere there was talk of a "Russian invasion" that would bring disorder and damage tourism. In Bern, only the staunch leadership of Albert Gobat, the responsible education official, prevented the government from cutting back sharply on the number of foreign women at the university (29, pp.11-12).

It is a remarkable fact that the political and academic authorities of Switzerland consistently supported the cause of women's higher education at a time when most of the world excluded women completely or partially from the best education available to men. That most of these women were foreigners and bearers of an unfamiliar culture and ideas makes the achievement even more impressive. A very large proportion of the Russian women were Jews severely restricted from university attendance at home. Some critics of the Swiss example argued that it was only the bourgeois greed of the Swiss for the money spent by students or the greed of the Swiss professors for more tuition money that made their position so liberal but surely these incentives existed also in Germany, Britain, or America. It was true that only a minority of the women completed the lengthy course of medical study in Switzerland but about 1600 women nevertheless received the M.D. degree from a Swiss university before 1914. Most of those who left their studies did so for reasons other than academic difficulties. In Russia itself, 73 per cent of the 1300 women who took their medical examinations during the first ten years of the women's medical courses there, many with some study in Switzerland, were successful $(25$, p. 10). The professors at all the Swiss universities consistently spoke highly of the women's performance, even those who had come poorly prepared. At Bern, for example, Russians won twelve of the twenty seminar prizes awarded in the university in 1898 (34, p.6). In the case of West European and American women, virtually all of them distinguished themselves in their later medical careers. Next to the Russians and the East Europeans, who comprised 80 per cent or more of the women medical students, the Germans and Austrians were the most numerous, followed at some distance by American and British women.

The First World War brought an end to the great migration of foreign women to Switzerland. By this time, most of the major nations of Europe and America were admitting women to their universities and medical schools. France had been the first to follow the Swiss example in medicine, when in 1868 an American, closely followed by three English, Russian, and French women, was matriculated at the University of Paris $(11$, p. 73). By 1900 , the University of Paris rivaled the Swiss universities in its attraction 
for foreign women, although the proportion of foreigners always remained considerably smaller (44, pp. 246, 259-62). Universities in the Low Countries, Italy, and Scandinavia followed in admitting women in the 1870's and 1880 's though the number of women in medicine remained very low $(25$, pp.12-17; 32, p.187). Some of the American state universities began to admit women to medicine after 1870 but a number of the great private schools in America were still closed to them in 1914. In Great Britain, likewise, women were only slowly and haltingly allowed into the major medical institutions of the country. The renowned universities of Germany, which had been the most resolutely closed of the European schools, began to admit women at Freiburg in 1899 and by 1908, with the capitulation of Prussia, all the universities of the Reich were open to them (14, pp. 36-8; 24, p.22).

The Swiss example was important everywhere in the battle for woman's right to study medicine. As early as 1869 , the faculty at Würzburg made an official inquiry of the academic senate at Zürich concerning the women who had enrolled in medicine and their effect on the university $(D$, letter of 23 December 1869). The response from Zürich was that the presence of women had caused no problems and that their "serious application to work and tactful behaviour" were largely responsible (D, 5 Feburary 1870). In the succeeding years, the Swiss schools sent similar responses, often at length, to inquiries from England, America, and other German universities. To an American inquiry, the Bern faculty responded in 1883 that its experience with women had been favorable and that "many colleagues welcome it" ( 36 , p. 103) and the Zürich faculty wrote in the same vein to an inquiry from the new Johns Hopkins University (C, May 23, 1890). The pages of the Boston Medical and Surgical Journal throughout the later nineteenth century contained numerous notices of the success of the experiment at Zürich (see e.g. 101 [1879] 67-9, 212, 567-8). In the case of Germany, the imperial government through its ambassador in Bern inquired officially in 1896 concerning the thirty years of Swiss experience with coeducation in medicine. The replies from the several medical faculties were uniformly positive, even enthusiastic. Said the noted psychiatrist August Forel, who had been a student when the first women came to Zürich: "I have (since) been teaching psychiatry for seventeen years ... and have never observed the slightest disadvantage to the coeducation of the sexes - on the contrary - the tone and behavior are far better than in an exclusively male student body" (12, p. 7). 
It was in Switzerland that for the first time in the modern world women studied medicine side-by-side with men in more than token numbers. The arguments for women's inferiority and incapability in medicine were answered there by experience. When Susan Dimock, the fourth woman to graduate in Zürich, returned to the woman's hospital in Boston, the German-born director and best known of all Boston's woman doctors, Marie Zakrzewska, wrote that "I am sorry to be forced to say that it is not the Republic of America which has given the proof that 'science has no sex', in so far as that it has furnished the largest number of women students. But it is the Republic of Switzerland which has verified this maxim. Our best women physicians have been educated there as well as in ... France" $(42$, p. 359). For half a century many of the best woman doctors in Russia, Germany, Austria, and Eastern Europe, as well as America, were trained in the classrooms and clinics of one of the smallest nations in the world. It was a remarkable achievement and deserves retelling in this time of renewed interest in the medical education of women.

\section{Bibliography}

\section{Archival Sources}

A Staatsarchiv Bern, Mappe der medizinischen Fakultät, Studierende, Frauenstudium, usw.

B Staatsarchiv Zürich, Frauenstudium 1864-1879, correspondence file in Box U94 16

C University of Zürich Archives, Protokoll der medicinischen Fakultät Zürich, 1864-1890 and $1890-1912$

D University of Zürich Archives, Senats-Protokoll, 1833-1880 and 1880-1910

\section{Published Material}

1 Albert, E.: Die Frauen und das Studium der Medicin. Alfred Hölder: Vienna 1895.

2 Benz, E.: Die Frauenbewegung in der Schweiz. Th. Schröter: Zürich 1902.

3 Bischoff, Th.: Das Studium und die Ausübung der Medicin durch Frauen. LiterarischArtistische Anstalt: München 1872.

4 Böhmert, V.: Das Frauenstudium nach den Erfahrungen an der Zürcher Universität. Leipzig 1874.

5 - Das Studieren der Frauen mit besonderer Rücksicht auf das Studium der Medicin. Otto Wigand: Leipzig 1872.

6 - Das Studium der Frauen an der Universität Zürich. Zürich 1870.

7 - Die zweite Doctorpromotion einer Dame in Zürich. Zürich 1870.

8 Cramer, M. and Starobinski, J.: Centenaire de la Faculté de médicine de l'Université de Genève (1876-1976): Documents. Editions Médecine et Hygiène: Genève 1978. 
9 Eidgenössisches Statistisches Amt: Schweizerische Hochschulstatistik 1890-1935. Bern 1935.

10 Erismann, F.: Gemeinsames Universitätsstudium für Männer und Frauen, oder besondere Frauen-Hochschulen? Berlin 1899.

11 Fontanges, Haryett: Les Femmes Docteurs en Médecine de tous les Pays. Alliance Coopérative du Livre: Paris 1901.

12 Forel, A.: Rückblick auf mein Leben. Zürich 1934.

13 Gagliardi, E. et al.: Die Universität Zürich 1833-1933. Verlag der Erziehungsdirektion: Zürich 1938.

14 Ganss, E.: Die Entwicklung des Frauenmedizinstudiums an deutschen Universitäten unter besonderer Berücksichtigung der Philipps-Universität in Marburg. Dissertation. Marburg 1983.

15 Henke, H.: Statistik der Universität Zürich in den ersten fünfzig Jahren ihres Bestehens von Ostern 1833 bis Ostern 1883. Zürcher u. Furrer: Zürich 1883.

16 - Statistik der Universität Zürich von Ostern 1883 bis Ostern 1896. Zürcher u. Furrer: Zürich 1896.

17 Hermann, L.: Das Frauenstudium und die Interessen der Hochschule Zürich. Zürich 1872.

18 Kirchoff, A.: Die akademische Frau: Gutachten hervorragender Universitätsprofessoren, Frauenlehrer und Schriftsteller über die Befähigung der Frau zum wissenschaftlichen Studium und Berufe. Hugo Steinitz Verlag: Berlin 1897.

19 Koller, H.: Das anatomische Institut der Universität Zürich in seiner geschichtlichen Entwicklung. Buch- und Kunstdruckerei A. Peter: Zürich 1926.

20 Meijer, J.: Knowledge and Revolution: The Russian Colony in Zürich (1870-1873). Van Gorcum \& Co.: Assen, Netherlands 1955.

21 Möbius, P.: Über den physiologischen Schwachsinn des Weibes. Verlag von Carl Marhold: Halle 1901.

22 Mysyrowicz, L.: Les Etudiants «Orientaux» en médecine à Genève. Gesnerus 34 (1977) 207-12.

23 Mysyrowicz, L.: Université et Révolution: Les Etudiants d'Europe Orientale à Genève au temps de Plékhanov et de Lénine. Revue Suisse d'histoire 25 (1975) 514-62.

24 Nauck, E.: Das Frauenstudium an der Universität Freiburg i.Br. Verlag Eberhard Albert Universitätsbuchhandlung: Freiburg 1953.

25 Neustätter, O.: Das Frauenstudium im Ausland. Verlag von August Schupp: München 1899.

26 Progin, M. \& Seitz, W.: Das Frauenstudium an der Universität Bern. Typewritten MS. Historisches Seminar: Universität Bern 1980.

27 Rohner, H.: Die ersten 30 Jahre des medizinischen Frauenstudiums an der Universität Zürich. Juris Druck \& Verlag: Zürich 1972.

28 Runge, M.: Das Weib in seiner geschlechtlichen Eigenart. Berlin 1900.

29 Saurer, J. \& Beran, G.: Ausländische Studierende an der Universität Bern 1834-1979. Typewritten MS. Historisches Seminar: Universität Bern 1980.

30 Scandola, P.: Die Dozenten der Bernischen Hochschule. Universität Bern: Bern 1984.

31 Scheel, H.: Frauenfrage und Frauenstudium. Rektoratsrede. Druck der Friedrich Mauke'schen Officin: Jena 1873. 
32 Schmidt-Harzbach, I.: Frauen, Bildung und Universität. In H.Prahl and I.SchmidtHarzbach: Die Universität: Eine Kultur- und Sozialgeschichte. Verlag C.J.Buchner: München 1981, 174-213.

33 Schultze, Caroline: La Femme-Médecin aux XIX ${ }^{\text {e }}$ Siècle. Libraire Ollier-Henry: Paris 1888.

34 Senn, A.: The Russian Revolution in Switzerland 1914-1917. Univ. of Wisconsin Press: Madison 1971.

35 Schirmacher, K.: Züricher Studentinnen. Verlag von Th. Schröter: Zürich 1896.

36 Schweizer. Verband der Akademikerinnen: Das Frauenstudium an den Schweizer Hochschulen. Rascher \& Cie Verlag: Zürich 1928.

37 Schwöbel-Schrafl, E.: Was verdankt die medizinische Fakultät Zürich ihren ausländischen Dozenten? 1833 bis 1863. Juris Druck \& Verlag: Zürich 1985.

38 Steudel, J.: Medical Women of the Occident. Journal of the American Medical Women's Assn 17 (1962) 52-55, 139-42.

39 Stites, R.: The Women's Liberation Movement in Russia: Feminism, Nihilism, and Bolshevism 1860-1930. Princeton Univ. Press: Princeton 1978.

40 Tiburtius, F.: Erinnerungen einer Achtzigjährigen. C.A. Schwetschke \& Sohn: Berlin 1929.

41 Die Verläumdung der in Zürich studirenden russischen Frauen durch die russische Regierung. Anonymous. Druck der Genossenschafts-Buchdruckerei: Zürich 1873. Contains full text of message of Russian government.

42 Vietor, A.: A Woman's Quest: The Life of Marie E.Zakrzewska, M. D. D. Appleton \& Co.: New York 1924.

43 Waldeyer, W.: Das Studium der Medizin und die Frauen. Allgemeine Wien. med. Ztg. (1888) $471,483$.

44 Weisz, G.: The Emergence of Modern Universities in France 1863-1914. Princeton University Press: Princeton 1983.

45 Woodtli, S.: Gleichberechtigung: Der Kampf um die politischen Rechte der Frau in der Schweiz. Verlag Huber \& Co.: Frauenfeld 1975.

46 Zehender, W.: Über den Beruf der Frauen zum Studium und zur praktischen Ausbildung der Heilwissenschaft. Stiller'sche Hof- und Universitätsbuchhandlung: Rostock 1875.

47 Zimmermann, W.: Südslavische Studenten in Zürich. Wegenetz Europäischen Geistes 8 (1983) 326-37. 


\section{Zusammenfassung}

In der Zulassung von Frauen zum Medizinstudium kommt den Schweizer Universitäten, zuerst Zürich, gefolgt von Bern, Genf und Lausanne eine Pionierrolle zu. In den sechziger Jahren des 19. Jahrhunderts wurden in Zürich die ersten Russinen zuerst zu den Vorlesungen, wenig später zu den Examen zugelassen. Den Russinen folgten bald auch Studentinnen aus den USA, England, Polen, Deutschland, Österreich und der Schweiz. Bis zum Ausbruch des Ersten Weltkriegs 1914 haben schätzungsweise 1600 Frauen in der Schweiz ihr medizinisches Studium abgeschlossen. In diesem Artikel wird dargestellt, welche gesellschaftlichen und politischen Zustände in verschiedenen Ländern das Frauenstudium verhinderten oder begünstigten.

Thomas N. Bonner

Professor of History

Wayne State University

Detroit, MI 48202

U.S.A. 